\title{
The Proterozoic Vazante Hypogene Zinc Silicate District, Minas Gerais, Brazil: A Review of the Ore System Applied to Mineral Exploration
}

\author{
Gema R. Olivo ${ }^{1, *}$, Lena V. S. Monteiro ${ }^{2}$, Fernando Baia ${ }^{3}$, Paul Slezak ${ }^{1,4}$, Igor Carvalho ${ }^{5}$, \\ Neil A. Fernandes ${ }^{1}$, Gustavo D. Oliveira ${ }^{3}$ (D) , Basilio Botura Neto ${ }^{3}$, Alexandra McGladrey ${ }^{1}$, \\ Adalene M. Silva ${ }^{5}$, Márcia A. Moura ${ }^{5}$ and Daniel Layton-Matthews ${ }^{1}$ \\ 1 Department of Geological Sciences and Geological Engineering, Kingston, ON K7L 3N6, Canada; \\ paul.r.slezak@gmail.com (P.S.); neil.fernandes@queensu.ca (N.A.F.); \\ AlexandraMcgladrey@gmail.com (A.M.); dlayton@queensu.ca (D.L.-M.) \\ 2 Geoscience Institute, University of São Paulo, São Paulo 05508-010, Brazil; lena.monteiro@usp.br \\ 3 Nexa Resources, Vazante 38780-000, Minas Gerais, Brazil; fernando.baia@nexaresources.com (F.B.); \\ gustavo.oliveira.go1@nexaresources.com (G.D.O.); basilio.neto@nexaresources.com (B.B.N.) \\ 4 Department of Geoscience, James Cook University, Townsville, QLD 4811, Australia \\ 5 Instituto de Geosciências, Universidade de Brasília, Brasília 70910-900, Federal District, Brazil; \\ igor@gfgeo.com.br (I.C.); adalene@unb.br (A.M.S.); mamoura@unb.br (M.A.M.) \\ * Correspondence: olivo@queensu.ca; Tel.: +1-613-533-6998
}

Received: 28 November 2017; Accepted: 10 January 2018; Published: 15 January 2018

\begin{abstract}
The Proterozoic Vazante zinc silicate district in Minas Gerais, Brazil, hosts world-class hypogene willemite deposits in dolomitic rocks interbedded with siliciclastic rocks deposited in subtidal to supratidal environments. Willemite ore bodies are structurally controlled along regional NE-trending structures which are interpreted as being active during the Neoproterozoic Brasiliano orogeny. The hydrothermal alteration is characterized by an early stage of Fe-dolomite, which replaced the host dolomitic rocks, followed by precipitation of minor sphalerite and then hematite and willemite. Elements commonly enriched in the zinc ore include $\mathrm{As}, \mathrm{Ba}, \mathrm{Be}, \mathrm{Bi}, \mathrm{Cd}, \mathrm{Co}$, $\mathrm{Fe}, \mathrm{Ge}, \mathrm{In}, \mathrm{Mo}, \mathrm{Ni}, \mathrm{Sb}, \mathrm{Se}, \mathrm{U}, \mathrm{V}$ and W. Mineralogical, fluid inclusion and isotopic data indicates that mixing of S-poor metalliferous saline fluids with meteoric water favored the formation of willemite ore. Carbonaceous phyllites from the underlying thick siliciclastic sequence show evidence of early enrichment in zinc (and ore-related metals) and remobilization, respectively, prior to and during the Brasiliano orogenic event. This unit is interpreted as a possible source of ore-related elements. It is proposed that during the Brasiliano orogeny, hot $\left(\mathrm{T}>170^{\circ} \mathrm{C}\right)$ saline fluids $(>15 \mathrm{wt} \%$ eq. $\mathrm{NaCl}$ ) leached metals from siliciclastic source rocks and precipitated willemite ore in the overlying dolomitic sequence along structures that favored mixing with oxidizing meteoric water.
\end{abstract}

Keywords: hypogene zinc silicate; willemite; Proterozoic dolomitic basin; Vazante district; mineral exploration; ore system model

\section{Introduction}

Zinc silicate deposits are usually high-grade ( 16 to $38 \mathrm{wt} \%$ ) and low in sulfide and lead content [1,2]. This makes them attractive targets for exploration as ore processing is easier and there is less environmental impacts from mining due to metal leaching and acid rock drainage. However, very few hypogene zinc silicate deposits have been mined (e.g., Vazante and the North Extension). It is not clear if this scarcity of deposits is because the processes related to their genesis are uncommon, or because most of the exploration programs worldwide are targeting sulfide-rich systems. Furthermore, due to the specific physical rock properties of hypogene sulfide ore (e.g., McGladrey et al. [3]), traditional 
geophysical methods applied to the exploration of sulfide deposits have not been very successful in finding zinc silicate deposits.

The Proterozoic Vazante Group, which is a carbonate sequence interbedded with siliciclastic rocks, hosts the world's largest hypogene zinc silicate deposits (the Vazante and North Extension mines) with various occurrences in the southern part, and $\mathrm{Pb}-\mathrm{Zn}$ sulfide deposits in the northern part (Paracatu District: Morro Agudo, Ambrósia (Figures 1 and 2, [4-9])). The Vazante mine hypogene willemite resources are estimated at $30.59 \mathrm{Mt}$ with $21 \% \mathrm{Zn}, 0.48 \% \mathrm{~Pb}$ and $33.57 \mathrm{ppm} \mathrm{Ag}$ and the North Extension resources at $6.48 \mathrm{Mt}$ with $18.35 \% \mathrm{Zn}, 0.30 \% \mathrm{~Pb}$ and $14.04 \mathrm{ppm} \mathrm{Ag}$ (NEXA Resources, internal data). Exploration drilling in the Varginha target area, located to the southeast of the Vazante mine (Figure 2), identified the occurrence of various mineralized intervals [9]. Recent evaluation of the resources in the Varginha target area indicates three major mineralized zones: (1) from 62.30 to $72.40 \mathrm{~m}$ depth with average $7.66 \% \mathrm{Zn}$; (2) from 523.80 to $533.05 \mathrm{~m}$ depth with $11.55 \% \mathrm{Zn}$; and (3) from 563.75 to $565.80 \mathrm{~m}$ depth with $17 \% \mathrm{Zn}$. Other minor occurrences found in a $15 \mathrm{~km}$ radius from the Vazante Mine include: Pamplona, Cercado and Olho d'Água which yielded Zn grades up to $21 \%, 12.3 \%, 1.4 \%$, respectively, and $\mathrm{Pb}$ contents between $0.27 \%$ and $1.7 \%$ [7].

Most papers on the ore system of the Vazante district have focused on the structural controls, alteration, ore mineralogy and geochemistry of specific deposits or occurrences $[5,6,8,10]$. There have also been some contributions on fluid evolution in the basin [9] and variations in the physical rock properties due to mineralization [3]. Several Proterozoic and Paleozoic carbonate sequences around the world have experienced a similar evolution to the Vazante Group, and these sequences could potentially host similar types of mineralization. Therefore, there is a need to have a comprehensive review of the hypogene zinc silicate system in the Vazante district to assist in improving the exploration strategies for this type of deposit at the district scale, and worldwide.

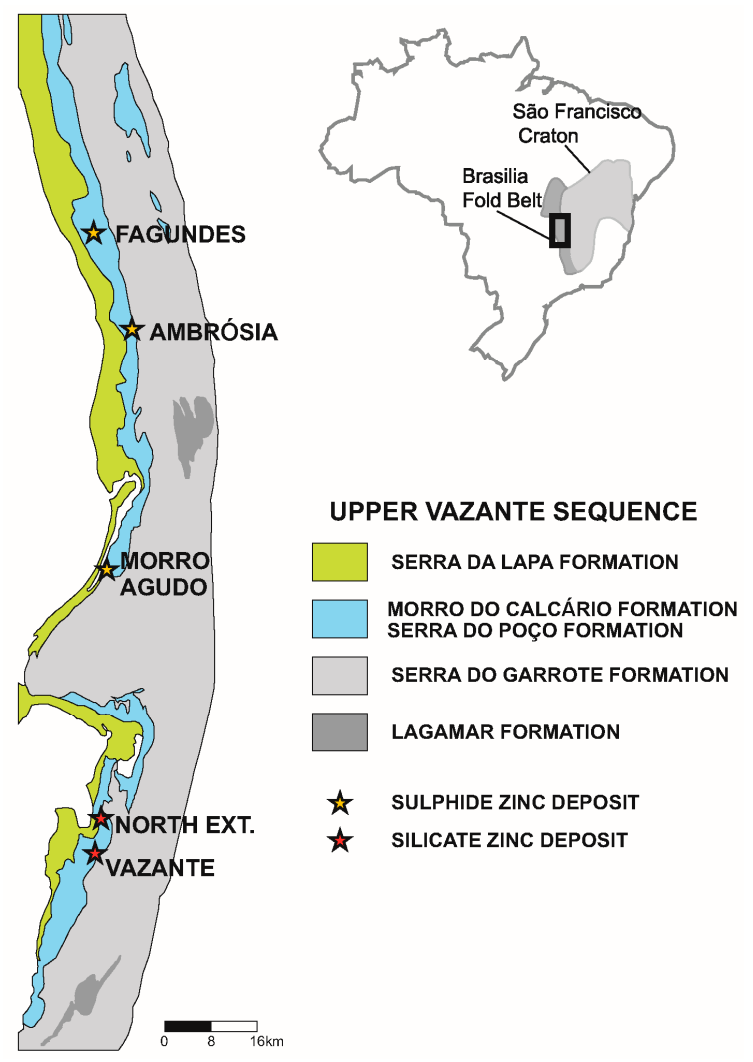

Figure 1. Geological Setting of the Vazante Group and the location of the major Pb-Zn sulfide deposits (Paracatu District) and the Zn silicate deposits (Vazante District). Modified from Nexa internal data. Inset map shows the location of the map area in Brazil in relation to the São Francisco Craton. 
This review aims to update the state of knowledge on the Vazante hypogene silicate ore system and to provide insightful guidelines for exploration that could be applied in similar geological settings. It highlights the major geological and geochemical controls at the regional and local scales, and discusses the critical processes involved in the formation of the deposits. The relevant parameters that should be taken into consideration when exploring for this type of deposit are summarized in the final section.

a)

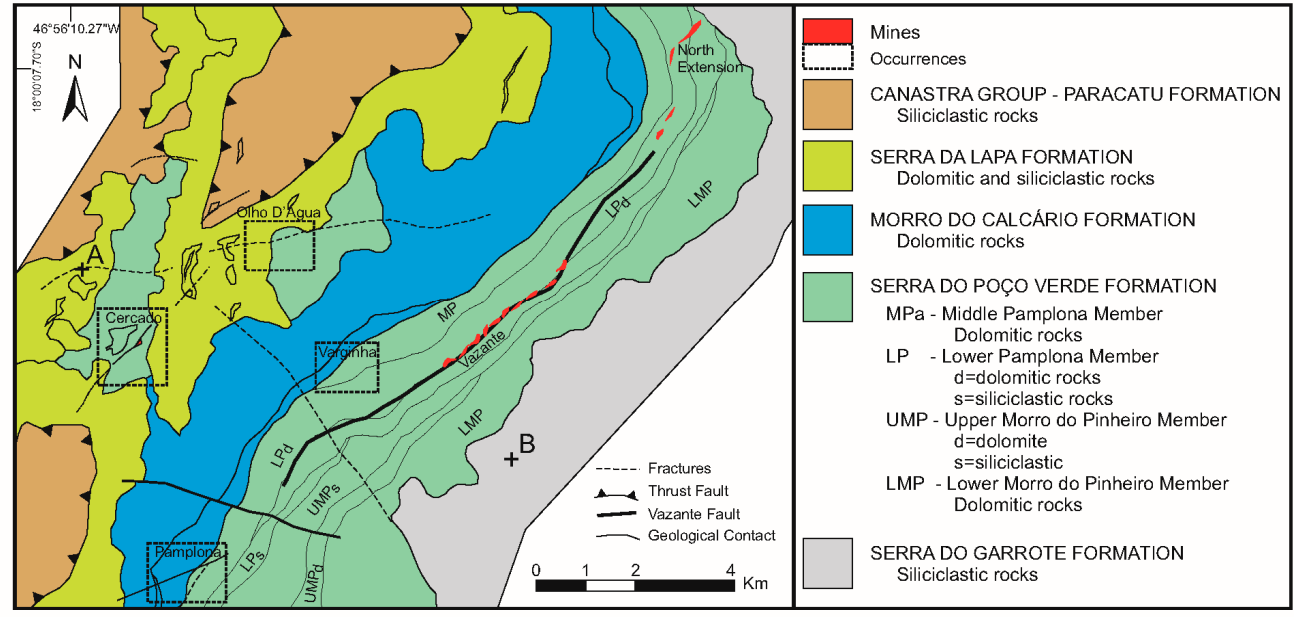

b)

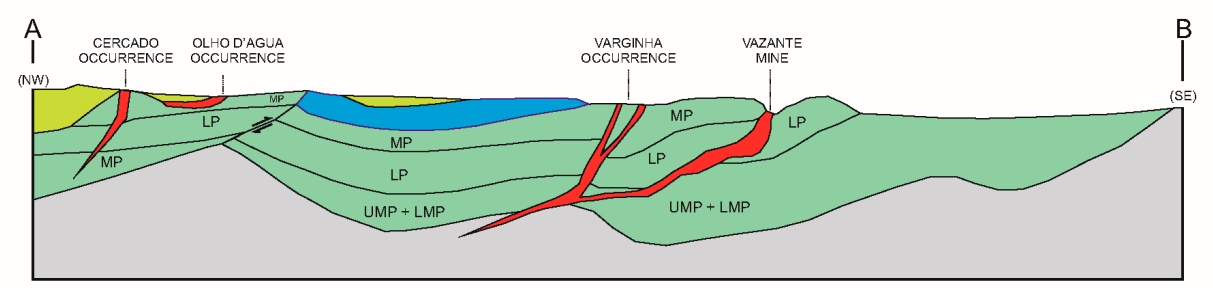

Figure 2. Geology of the Vazante District showing the location of $\mathrm{Zn}$ silicate mines and occurrences: (a) Geological map (modified from Baia [7]), and (b) Schematic geological section along A-B (compiled from NEXA Resources internal data).

\section{Tectonic and Geological Setting}

The Vazante Group is located in the western margin of the São Francisco Craton, between the eastern limit of the Brasília Fold Belt [11] and western boundary of the São Francisco Basin [12]. The Vazante Group units are in tectonic contact, delineated by major regional thrust faults, with the Canastra Group in the western region and the Bambuí Group in the eastern sector [11,13]. The Vazante Group comprises a sequence of carbonate (mostly dolomite) and siliciclastic rocks covering an area of approximately $250 \mathrm{~km}$ along a N-S striking region, with an average width of 25 to $30 \mathrm{~km}$ (Figure $1 ;[7,9,13])$. There are conflicting interpretation of the depositional setting of the Vazante Group. Various authors have proposed that the sediments were deposited in a passive margin setting on the western border of the São Francisco craton [11,14]; however, other researchers have proposed a foreland basin setting $[15,16]$. Recent geochemical investigation of the siliciclastic units indicated that the sediments were sourced mainly from felsic volcanic rocks derived from continental arcs rather than mature recycled rocks typical of passive continental margins [17].

The original stratigraphic sequence of the Vazante Group was proposed by Dardenne et al. [15] and Dardenne [13] and was comprised of the following units from the base to the top (Figure 3): Retiro (also referred to as Santo Antônio do Bonito), Rocinha, Lagamar, Serra do Garrote, Serra do Poço Verde (host of the zinc silicate mineralization), Morro do Calcário (host of the $\mathrm{Pb}$-Zn sulfide mineralization) and Serra da Lapa formations. The main characteristics of these units are summarized in Figure 3. Misi et al. [14] have proposed that the lower part of the sequence, including the Santo Antônio do Bonito and Rocinha formations, are younger (Neoproterozoic) than the upper sequence (late Mesoproterozoic), 
based on Re-Os ages in organic-rich shales [18,19], and U-Pb data on detrital zircon in siliciclastic rocks scattered throughout the succession [20] (Figure 3). Based on this data and field relationships, Misi et al. [14] further suggested that the upper sequence (from Lagamar to Serra da Lapa formations) were thrust over the lower sequence. However, the age of the Vazante Group is still subject to debate, as the Re-Os data was from organic-rich siliciclastic units which exhibit clear evidence of various episodes of fluid-rock interaction [17]. Sm-Nd data from metasedimentary rocks from the Vazante Group yielded $\mathrm{T}_{\mathrm{DM}}$ values ranging from 2100 to $1700 \mathrm{Ma}$ [11], which are midway between data from the Paranoá $\left(\mathrm{T}_{\mathrm{DM}}=2300\right.$ to $\left.2000 \mathrm{Ma}\right)$ and Bambuí $\left(\mathrm{T}_{\mathrm{DM}}=1900\right.$ to $\left.1400 \mathrm{Ma}\right)$ groups, supporting the interpretation that the stratigraphic position of the Vazante Group is at the top of the Paranoá sequence and at the base of the Bambuí Group [11,12,21].

The upper sequence of the Vazante Group is exposed along an arcuate belt with westward concavity (Figure 1). This belt can be divided into two sectors with distinct stratigraphic, structural and metallogenic features separated by the central inflexion in the Rio Escuro region (Figure 1). The zinc silicate deposits are hosted in the southern part of the Rio Escuro inflexion (Figures 1 and 2); whereas, the northern sector contains significant $\mathrm{Zn}-\mathrm{Pb}$ sulfide deposits (Morro Agudo, Ambrósia and Bomsucesso) and occurrences (e.g., Fagundes, Poções, Mocambo and Retiro). The Vazante Group rocks were affected by lower greenschist facies metamorphism and by at least three deformation events [5,8,22-26]. A Rb-Sr whole rock isochron for shales from the Vazante Group yielded an age of $600 \pm 50 \mathrm{Ma}$ [27], which is understood to be the closure of the isotopic systems during the Brasiliano metamorphic event [5].

\begin{tabular}{|c|c|c|c|c|c|c|c|}
\hline \multicolumn{2}{|c|}{ Formation } & Member & $\begin{array}{c}\text { Thicknes } \\
\mathrm{s} \\
(\mathrm{m}) \\
\end{array}$ & Description & $\begin{array}{l}\text { Depositional } \\
\text { Environment }\end{array}$ & Age Constrains & $\begin{array}{l}\text { Base Metal } \\
\text { Deposits }\end{array}$ \\
\hline Eニニニニニ & $\begin{array}{l}\text { Serra da } \\
\text { Lapa }\end{array}$ & & 650 & $\begin{array}{l}\text { Grey carbonate-rich } \\
\text { slate, } \\
\text { lenses of dolomite } \\
\text { carbonaceous slate }\end{array}$ & Subtidal & $\begin{array}{l}\text { U-Pb zircon: } 1082 \pm 14 \mathrm{Ma} \\
\text { Tом=1.72-1.91Ga }\end{array}$ & \\
\hline A & $\begin{array}{l}\text { Morro do } \\
\text { Calcário }\end{array}$ & $\begin{array}{l}\text { Upper } \\
\text { Pamplona }\end{array}$ & $200-300$ & $\begin{array}{l}\text { Stromatolitic bioherm, } \\
\text { dolomite breccia and } \\
\text { doloarenite } \\
\text { Basal dark grey } \\
\text { siltistone }\end{array}$ & $\begin{array}{l}\text { Supratidal } \\
\text { Storm beach }\end{array}$ & $\begin{array}{l}\text { U-Pb zircon: } 1137 \pm 8 \mathrm{Ma} \\
\text { Re-Os: } 1112 \pm 50 \mathrm{Ma}\end{array}$ & $\begin{array}{l}\text { Sulfide Pb-Zn } \\
\text { Morro Agudo } \\
\text { Ambrosia, } \\
\text { Fagundes } \\
\text { Bomsucesso }\end{array}$ \\
\hline & \multirow{4}{*}{$\begin{array}{l}\text { Serra } \\
\text { do } \\
\text { Poço } \\
\text { Verde }\end{array}$} & $\begin{array}{l}\text { Middle } \\
\text { Pamplona }\end{array}$ & 400 & $\begin{array}{l}\text { Pink dolomite with } \\
\text { stromatolitic mats and } \\
\text { mud cracks }\end{array}$ & \begin{tabular}{|l} 
Subtidal to \\
intertidal
\end{tabular} & $\mathrm{T}_{\mathrm{DM}}=1.82-2.10 \mathrm{Ga}$ & \multirow{3}{*}{$\begin{array}{l}\text { Silicate Zn: } \\
\text { Vazante, } \\
\text { North } \\
\text { Extension, } \\
\text { Varginha, } \\
\text { Olho d'Agua } \\
\text { Cerrado, } \\
\text { Pamplona } \\
\end{array}$} \\
\hline & & $\begin{array}{l}\text { Lower } \\
\text { Pamplona }\end{array}$ & $100-200$ & $\begin{array}{l}\text { Grey and green slate, } \\
\text { siltstones with pink } \\
\text { dolomite }\end{array}$ & $\begin{array}{l}\text { Intertidal, } \\
\text { supratidal to } \\
\text { Sabkha }\end{array}$ & & \\
\hline & & $\begin{array}{l}\text { Upper Morro } \\
\text { do Pinheiro }\end{array}$ & $300-500$ & $\begin{array}{l}\text { Dark grey dolomite } \\
\text { with stromatolitic mats } \\
\text { and fenestrae }\end{array}$ & $\begin{array}{l}\text { Subtidal to } \\
\text { intertidal }\end{array}$ & & \\
\hline & & $\begin{array}{l}\text { Lower Morro } \\
\text { do Pinheiro }\end{array}$ & 500 & $\begin{array}{l}\text { Light gray to pink } \\
\text { dolomite with } \\
\text { intercalations of breccia } \\
\text { and doloarenite } \\
\end{array}$ & $\begin{array}{l}\text { Subtidal to } \\
\text { intertidal }\end{array}$ & & \\
\hline$E=$ & $\begin{array}{l}\text { Serra do } \\
\text { Garrote }\end{array}$ & & $>1000$ & $\begin{array}{l}\text { Grey slate to phyllite } \\
\text { with C-rich layers and } \\
\text { minor quartzite } \\
\text { intercalations }\end{array}$ & $\begin{array}{l}\text { Shallow } \\
\text { marine }\end{array}$ & $\begin{array}{l}\text { U-Pb zircon: } 1296 \pm 13 \mathrm{Ma} \\
\text { Re-Os: } 1354 \pm 88 \mathrm{Ma} \\
\text { T⿰м= } 2.03-2.05 \mathrm{Ga}\end{array}$ & \\
\hline$\hat{\kappa} \hat{\wedge}$ & Lagamar & Sumidoro & 250 & $\begin{array}{l}\text { Limestone, dolomite } \\
\text { breccia with } \\
\text { stromatolitic bioherm in } \\
\text { the top }\end{array}$ & $\begin{array}{l}\text { Intertidal } \\
\text { facies }\end{array}$ & & \\
\hline \multirow[t]{2}{*}{000000000} & & Arrependido & & Conglomerate & & & \\
\hline & Rocintha & & 1000 & $\begin{array}{l}\text { Rhythmites with } \\
\text { phosphatic slates }\end{array}$ & $\begin{array}{l}\text { Shallow } \\
\text { marine }\end{array}$ & 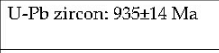 & \\
\hline $\begin{array}{l}10000000000000000 \\
\end{array}$ & \begin{tabular}{|l|} 
Retiro \\
(Santo \\
Antonio \\
do Bonito) \\
\end{tabular} & & 250 & $\begin{array}{l}\text { Intercalations of } \\
\text { quartzite, phosphorite, } \\
\text { diamictite and slates }\end{array}$ & Glacio-marine & U-Pb zircon: $997 \pm 29 \mathrm{Ma}$ & \\
\hline
\end{tabular}

Figure 3. The lithostratigraphic framework of the Vazante Group (based on Dardenne [13]) showing the hosts of the zinc silicate mineralization and age constraints for the various units. Depositional environment from Dardenne, [13]; Azmy et al. [18]; Oliveira, [28] and Slezak et al. [8]. U-Pb ages for the youngest detrital zircon from Rodrigues et al. [20]; Re-Os ages from Geboy et al. [19] and Azmy et al. [18]; Sm-Nd data (T $\left.\mathrm{T}_{\mathrm{DM}}\right)$ from Pimentel et al. [11]. The double line indicates thrust fault between the lower Neoproterozoic units and the upper Late Mesoproterozoic units according to Misi et al. [14]. 
The Vazante rocks were cut by mafic dikes, which are deformed and metamorphosed. These dikes yielded $\mathrm{Sm}-\mathrm{Nd} \mathrm{T}_{\mathrm{DM}}$ model ages between 1.16 to $1.21 \mathrm{Ga}$, and $\varepsilon_{\mathrm{Nd}}(0)$ in the range of +0.16 to -0.41 [29]. The $\mathrm{T}_{\mathrm{DM}}$ ages are interpreted by these authors to overestimate the age of emplacement and to represent the maximum crystallization age of the dikes. This interpretation is based on the fact that the $\mathrm{Sm} / \mathrm{Nd}$ ratios are very fractionated $(+0.16)$, and these rocks exhibit evidence of crustal contamination, containing basement-derived Paleoproterozoic zircon grains.

\section{Stratigraphic Controls}

The zinc silicate mineralization is hosted mainly in the dolomitic rocks of the Serra do Poço Verde Formation (Figures 2 and 3). This formation is in contact with the Serra do Garrote Formation at the bottom and the Morro do Calcário Formation at the top. According to Rigobello et al. [30] and Dardenne [13], the Serra do Poço Verde Formation is divided into four members from the base to the top (Figure 3): (1) the Lower Morro do Pinheiro Member, composed mainly of dolomite with intercalations of breccia and doloarenite; (2) the Upper Morro do Pinheiro Member, comprised of dolomite with microbial mats and fenestrae intercalated with dolarenite, lamellar breccia and minor carbonaceous shale; (3) the Lower Pamplona Member, composed of slates and phyllites, micritic dolomite, commonly pinkish, with microbial mats; and (4) the Middle Pamplona Member, composed of dolomite with microbial mats, laminations and mud cracks intercalated with dolarenite and lamellar breccia. These units are interpreted to have formed in subtidal to supratidal environments, transitional to sabkha [8,31-33].

The Vazante (Figure 4) and North Extension (Figure 5) zinc silicate deposits are hosted mainly at the contact of the Upper Morro do Pinheiro and the Lower Pamplona Members [5,6,8,9]. However, some occurrences (Figures 2 and 3) have also been found in the intermediate zone of the Upper Morro do Pinheiro dolomite and phyllite (Figure 2, Varginha; and Figure 4 in Carvalho et al. [9]), and at the tectonic contact of an undifferentiated carbonate unit, that was tentatively correlated to the Morro do Calcário Formation with the Lapa Formation by Baia [7] (Cercado and Olho d'Agua). Recent drill core logging in the Cercado (Figure 6a) and Olho d'Água occurrence (Figure 6b) revealed that the carbonate unit sits directly on the siliciclastic rocks of the Serra do Garrote Formation, and it is therefore interpreted in this study to be correlated with the Serra do Poço Verde Formation. The Pamplona occurrence is hosted at the top of the Serra do Poço Verde Formation (Figure 6c).

Overall, the bulk of the mineralization occurs mainly in dolomite units interbedded with thin layers of siliciclastic rocks that were deposited in subtidal to supratidal, and sabkha environments. These units are commonly in tectonic contact or underlain by a thick sequence of siliciclastic rocks. 
a)

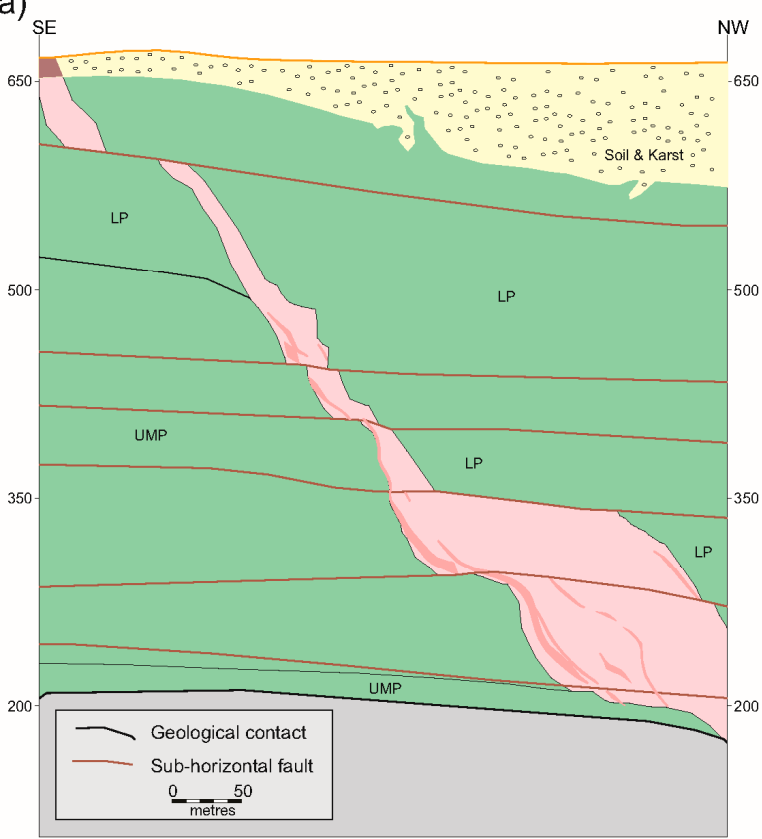

b)
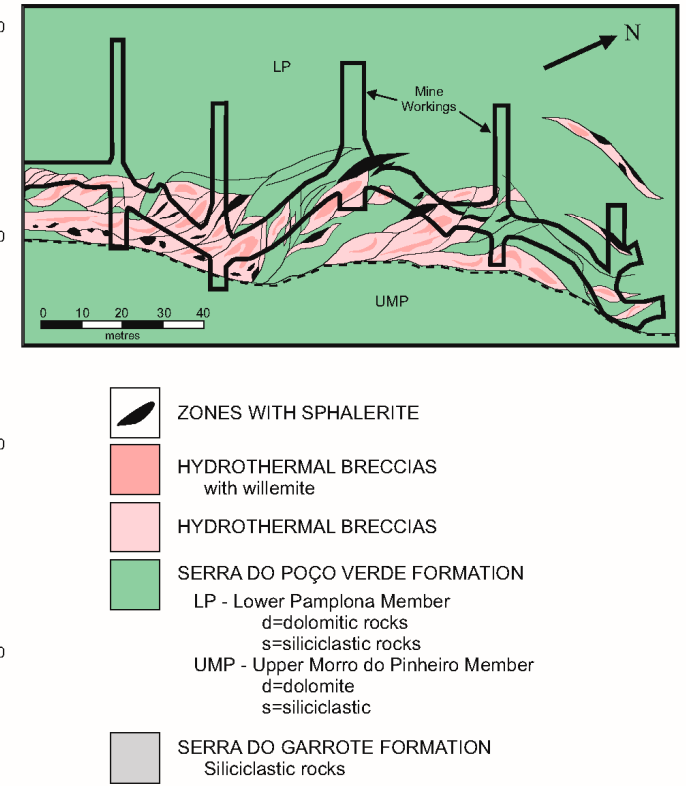

Figure 4. The Vazante Mine: (a) Geological section (SE-NW) showing the geometry of willemite-bearing hydrothermal breccia compiled from Nexa mine data 2017; (b) Plan view of the level 500 of the Vazante mine showing the relationship between the major willemite orebody and the lenses with sphalerite (modified from Monteiro [33]).

a)

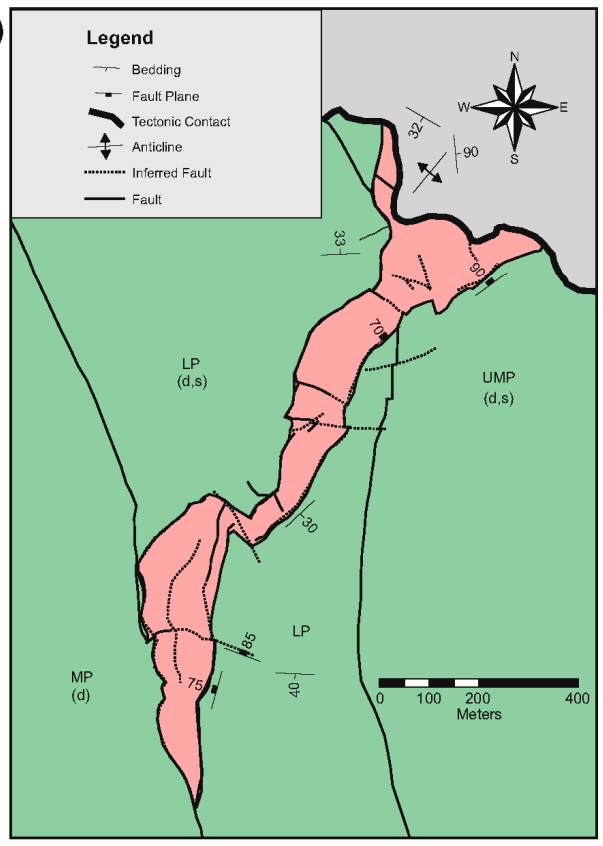

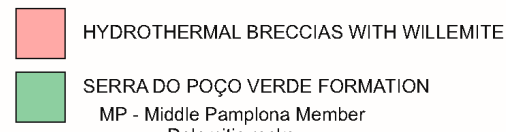
MP - Middle Pamplona Member Dolomitic rocks
LP - Lower Pamplona Member $\mathrm{d}=$ dolomitic rocks $s=$ siliciclastic rocks
UMP - Upper Morro do Pinheiro Member $\mathrm{d}=$ dolomite LMP - Lower Morro do Pinheiro Member Dolomitic rocks

SERRA DO GARROTE FORMATION Siliciclastic rocks

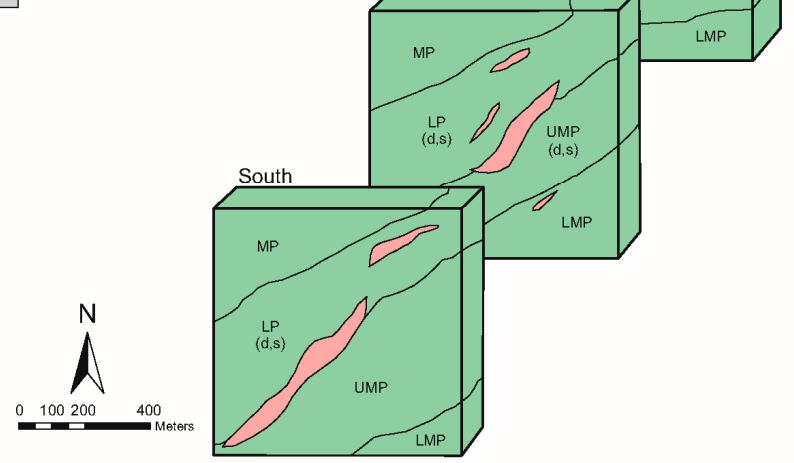

Figure 5. The North Extension deposit: (a) Geological map of pits 5A, 6A, and 7A in the northernmost section of the Northern Extension Mine (modified from Votorantim base map and Slezak et al. [8]); (b) Block diagram of the Northern Extension showing the geometry of the hydrothermal breccias containing willemite ore (modified from Slezak et al. [8]). For location of the North Extension deposit see Figures 1 and 2. 
a)
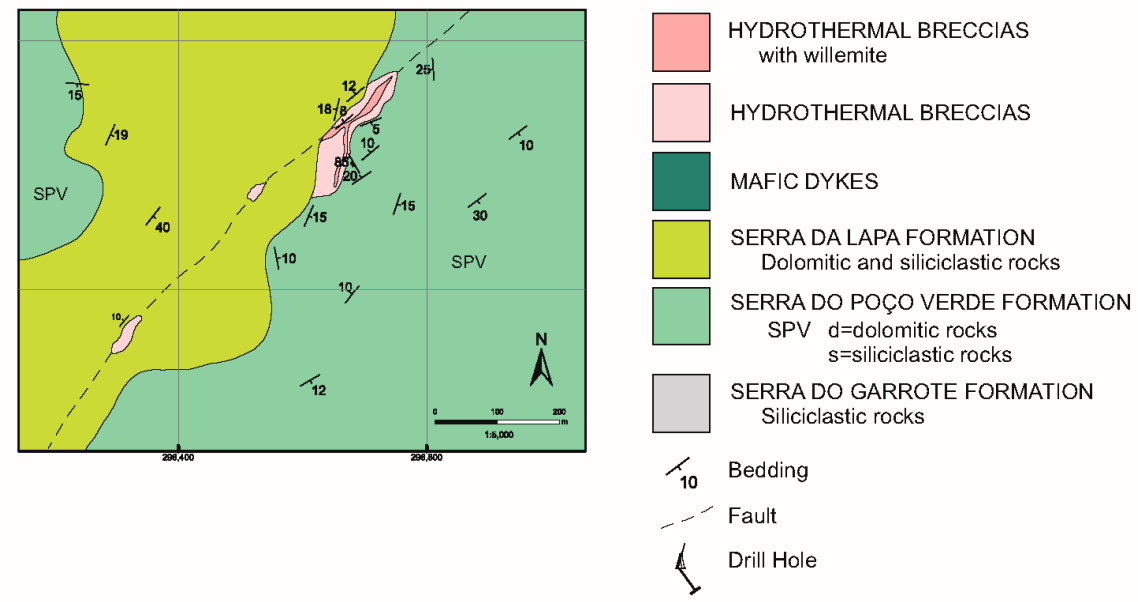

b)

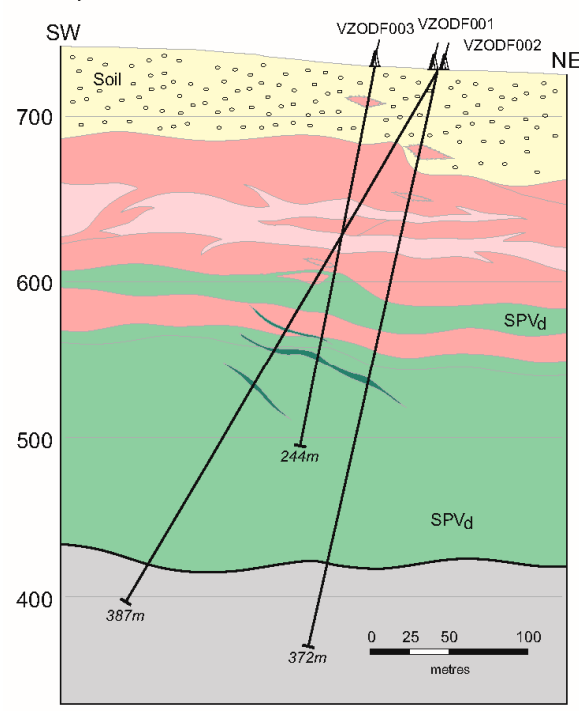

c)

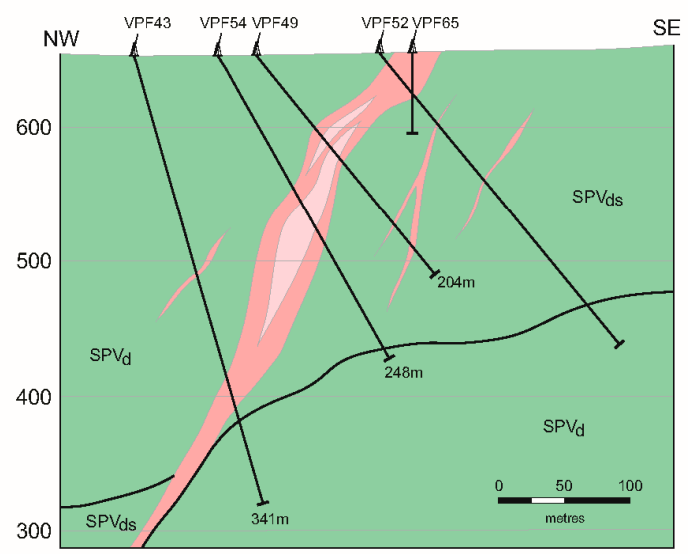

Figure 6. Other willemite occurrences: (a) Geological map of the Cercado occurrence; (b,c) Geological sections showing the mineralized zones of the Olho d'Agua and the Pamplona occurrences, respectively (modified from Baia [7]; this study). For location of the occurrences see Figure 2.

\section{Structural Controls and Ore Body Geometry}

Zinc silicate mineralization in the Vazante Mine occurs in hydrothermally altered (mainly Fe-carbonate and hematite) and brecciated dolostone interbedded with slate, phyllite and mafic dikes along a fault that strikes N50E and dips $60^{\circ}-70^{\circ}$ NW (Figure 2; $[4-6,10,13]$ ). This major structure is clearly envisaged by the responses of the high gradient signal in its first vertical derivative of the anomalous magnetic field (Figure 7, modified from Baia [7] and McGladrey, [34]). The fault was interpreted as an early syn-sedimentary growth fault that underwent multiple reactivations during the Brasiliano Orogeny, including reverse faulting during compression that later evolved into a normal, sinistral fault during the orogenic event $[4,13,24]$. The fault zone in the Vazante deposit displays features typical of both brittle and ductile deformation, represented by brecciation and a weak mylonitic (S-C) fabric, respectively [4]. The Vazante ore body extends for nearly $5 \mathrm{~km}$ along strike (Figure 2) and over $500 \mathrm{~m}$ below the surface, being tens of meters thick (Figure 4). The high-grade zones form pods within the hydrothermally altered and brecciated host (Figure 4). 


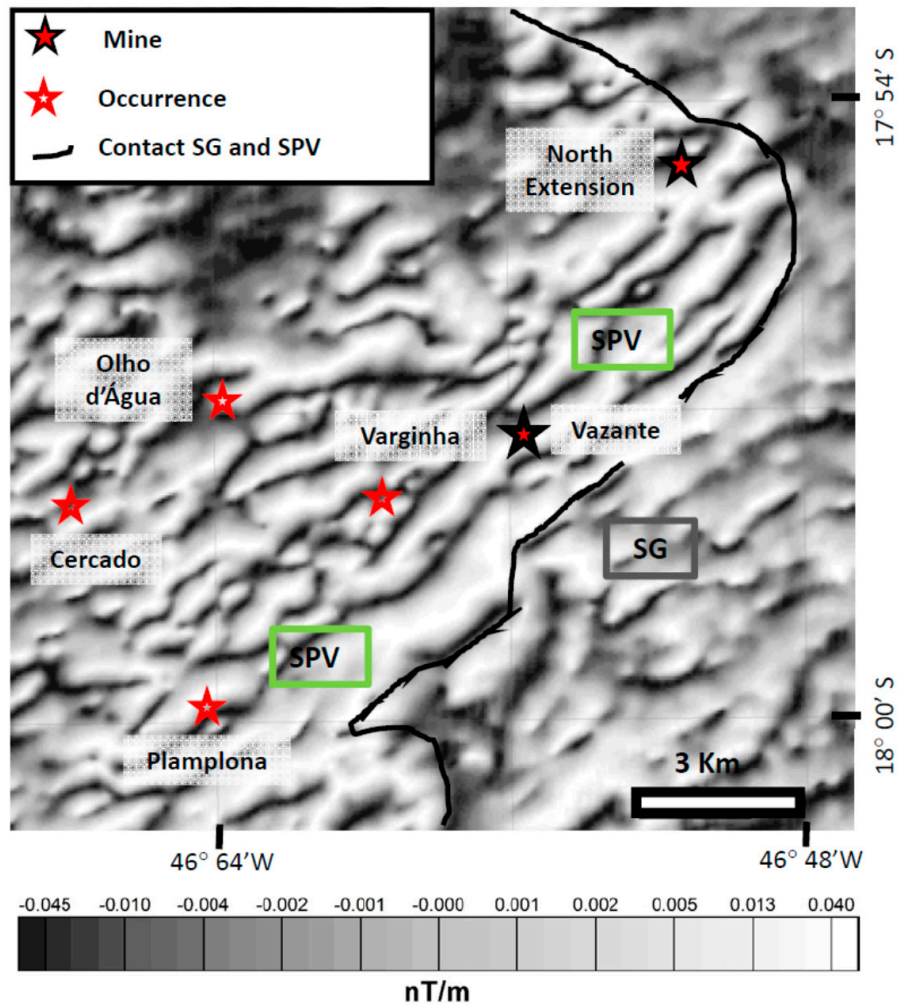

Figure 7. First vertical derivative of the anomalous magnetic field in the Vazante District showing the main regional fault that controls the zinc silicate deposits and the other structures controlling the occurrences. This derivative product enhances patterns that define the structures that control the mineralization (modified from Baia [7] and McGladrey, [34]) (SG = Serra do Garrote; SPV = Serra do Poço Verde).

The Northern Extension ore bodies occur within major tectonic-hydrothermal breccias in a NE-trending fault zone (Figures 2, 5 and 7). This zone and the ore-bearing tectonic-hydrothermal breccia are bounded by two faults both oriented N30E, and one dipping to $30^{\circ} \mathrm{NW}$ and another $55^{\circ}$ SE (Figure 5; Slezak et al. [8]). These faults are subparallel to the regional fold axis plunging to the $\mathrm{SE}$, and the breccias exhibit more brittle features such as joints, fractures, and displaced blocks than those seen at the Vazante Mine. Willemite occurs as massive pods in hydrothermal breccias (Figure 5). The faults and the breccias are interpreted to be formed during the major deformation event which is related to the Neoproterozoic Brasiliano Orogeny $[4,8]$. The faults were reactivated during their evolution and are cut by later transcurrent faults and fractures, which locally host the supergene (mainly hemimorphite and smithsonite) ore [8]). These faults may be related to reactivation of basement or early syn-sedimentary structures.

The Pamplona occurrence (Figures $6 \mathrm{c}$ and 7 ) is along an ENE fault $\left(\mathrm{N} 70 \mathrm{E} / 60^{\circ} \mathrm{NW}\right.$ ), in the southern edge of the Vazante fault zone, whereas the Mina do Cercado willemite occurrence (Figures 6a and 7) is adjacent to a N35E $/ 75^{\circ} \mathrm{NW}$ fault [7]. The Olho d'Água occurrence is characterized by thin lenses containing willemite and franklinite and enveloped by hydrothermal breccia ( $20 \mathrm{~m}$ thick, $80 \mathrm{~m}$ long and 100 deep) along a N45E $/ 30^{\circ} \mathrm{NW}$ trend (Figure $6 \mathrm{~b}$; [7]). The host rocks are cut by mafic dikes.

Therefore, the reactivation of major faults during the orogenic event was relevant in structurally controlling the large deposits. In the Vazante district, these structures are oriented mainly NE and may represent reactivation of basement or syn-sedimentary structures. 


\section{Hydrothermal Alteration and Ore: Mineralogy and Geochemistry}

The early stages of hydrothermal alteration associated with the hypogene zinc silicate mineralization at Vazante, North Extension and Varginha are characterized mainly by Fe-bearing dolomite (Figure 8a), with local siderite and minor quartz. These minerals filled dissolutions zones and veinlets, and cemented clasts within the brecciated dolomitic rock $[5,6,8,9]$. The intensity of the Fe-carbonate alteration commonly increases towards the core of the mineralized system. The subsequent stage of alteration, commonly proximal to the ore zone, is characterized by high proportions of hematite (Figure $8 \mathrm{a}-\mathrm{d}$ ) with minor quartz, which replaced the host dolomite and hydrothermal Fe-bearing dolomite, filled veinlets and cemented the hydrothermal breccia. Hematite is more abundant in the North Extension mine than in the Vazante mine (Figure 8d). The onset of hematite precipitation commonly preceded the formation of willemite, and both minerals continued to precipitate during the main ore stage (Figure $8 \mathrm{~b}$ ) along with minor franklinite, zincite and rare smithsonite. The abundance of franklinite increases with proximity to mafic dikes [3]. The mafic dikes are hydrothermally altered and contain minor Zn-chlorite, sphalerite, and franklinite. In the Vazante Mine, lenses with sphalerite and galena coeval with early Zn-rich hematite, as well as late sphalerite veinlets have been reported [6]. In the North Extension mine and Varginha occurrence, rare galena was observed associated with early hematite, however, the most common occurrence of sulfides is as late veinlets cutting the willemite ore or filling dissolution zones (Figure 8e,f) [8,9]. The sulfides include galena, sphalerite, chalcocite, stromeyerite and covellite (Figure 8e,f). Native silver was observed locally associated with $\mathrm{Cu}$-sulfides [8]. These sulfides have been interpreted as late hydrothermal [8,9]; however, it was not possible to determine the absolute timing of this event. Apatite, Zn-chlorite, barite and anglesite formed in the late stages. The overall paragenetic sequence for the Vazante zinc silicate district is illustrated in Figure 9.
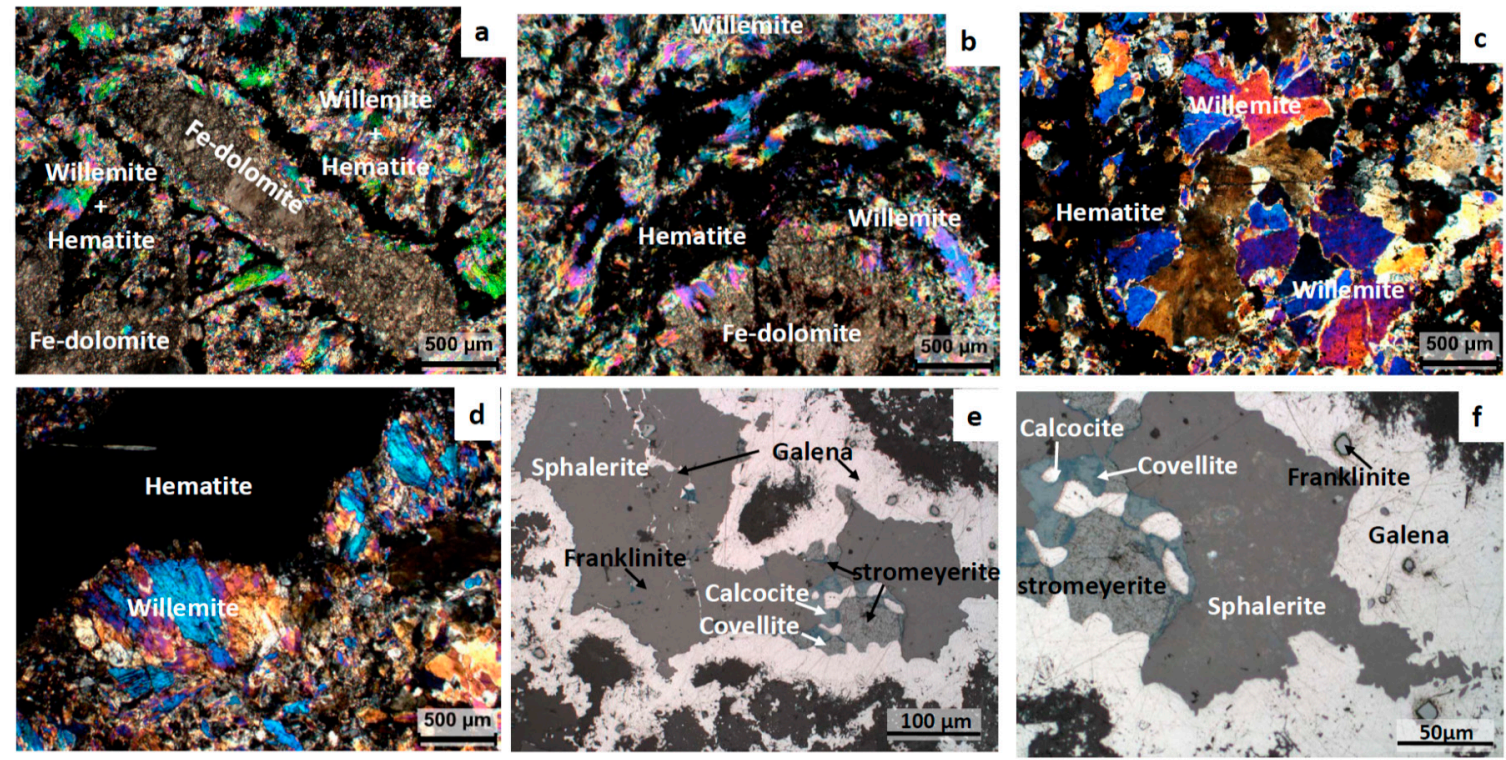

Figure 8. Photomicrographs with crossed-polarized light (a-d) illustrating the typical characteristics of the willemite ore in the Vazante mine ( $(\mathbf{a}-\mathbf{c})$ : sample \# Mine 9) and North Extension (sample \#186-354 (d)): (a) Remnant of altered host dolomite replaced by Fe-dolomite and mantled by hematite and willemite; (b) Oscillatory zones with hematite and willemite filling corroded zones in Fe-dolomite altered host rock; (c) Willemite as granular and platy crystals associated with hematite; (d) Hematite overgrowth by fibrous willemite; (e,f) Reflected light photomicrographs showing the late sulfide veinlets with sphalerite, galena, stromeyerite, chalcocite and covellite (sample \#069-136A from North Extension). 


\begin{tabular}{|l|l|l|}
\hline Minerals & $\begin{array}{l}\text { Diagenesis to } \\
\text { Pre-Orogenesis }\end{array}$ & Early \\
\hline $\begin{array}{l}\text { Dolomite } \\
\text { Quartz } \\
\text { Clay }\end{array}$ & & \\
Fe-dolomite \\
Hematite
\end{tabular}

Figure 9. Paragenetic sequence for the Vazante and North Extension deposits and Varginha occurrence (Data from Monteiro et al. [5,6]; Slezak et al. [8]; Carvalho et al. [9]; and this study).

The hydrothermally altered dolomites and ore zones are enriched in the following elements when compared with unaltered rocks: As, Ba, Be, Bi, Cd, Co, Fe, Ge, Hg, In, Mo, Ni, Sb, Se, U, V, and W, Zn [8]. Hematite-rich zones have the highest concentrations in $\mathrm{As}, \mathrm{Ba}, \mathrm{Bi}, \mathrm{Fe}, \mathrm{Ge}, \mathrm{In}, \mathrm{Mo}, \mathrm{Ni}, \mathrm{Sb}, \mathrm{Sn}, \mathrm{U}, \mathrm{V}$, and $\mathrm{W}$, and willemite ore has the highest average concentrations of $\mathrm{Ag}, \mathrm{Cu}, \mathrm{Hg}, \mathrm{Pb}, \mathrm{S}, \mathrm{Se}, \mathrm{SiO}_{2}$, and $\mathrm{Zn}$. Calcium and $\mathrm{Mg}$ concentrations decrease significantly from Fe-carbonate altered rocks to hematite and willemite brecciated zones [8]. Because the hydrothermal alteration involved significant dissolution of the host rock followed by brecciation and in-filling with hydrothermal phases [8], it is difficult to quantify the exact amount of metal enrichment. Due to the sporadic nature of the sulfide phases, precise changes in the elements $\mathrm{Ag}, \mathrm{Cu}, \mathrm{S}$, and $\mathrm{Pb}$ are particularly difficult to determine. Overall, As, $\mathrm{Cd}, \mathrm{Hg}$, In, Mo, $\mathrm{Sb}$ and Se amounts in the ore are 1000 times the values in the host dolomite, and $\mathrm{Zn}$ is in the order of 100,000 times [35].

The data suggests that the hydrothermal fluids that interacted with the host rocks during Fe-carbonate alteration were enriched in $\mathrm{Zn}$ and other ore-related elements. However, there were relevant changes in the hydrothermal system, as it evolved from a carbonate-dominant alteration, where iron occurs as $\mathrm{Fe}^{2+}$, to a hematite-dominant alteration $\left(\mathrm{Fe}^{3+}\right)$. There was also an increase in silica, which is required to precipitate high amounts of willemite in Si-poor dolomitic rocks. The late stage sulfide veinlets have a distinct metallic association, containing $\mathrm{Cu}$ - and $\mathrm{Ag}$-bearing minerals that indicate different fluid sources compared to the zinc silicate system.

\section{Hydrothermal Fluids: Fluid Inclusion and Isotopic Constraints}

The evolution of the fluids associated with the host rocks from the Serra do Poço Verde Formation is well documented in Carvalho et al. [9] and fluid inclusions for the Vazante ore are reported in Dardenne and Freitas-Silva [10] and Monteiro [33]. The fluids that circulated in the host dolomites prior to the main ore stage were $\mathrm{H}_{2} \mathrm{O}-\mathrm{NaCl}-\mathrm{CaCl}_{2} \pm \mathrm{MgCl} \pm \mathrm{FeCl}$ fluids with salinities varying from 7 to $20 \mathrm{wt} \%$ equivalent $\mathrm{NaCl}\left(\%\right.$ eq. $\mathrm{NaCl}$ ) at temperatures of homogenization $\left(\mathrm{T}_{\mathrm{h}}\right)$ ranging from $75{ }^{\circ} \mathrm{C}$ during diagenesis to $148^{\circ} \mathrm{C}$ in the early hydrothermal dolomite and quartz [9]. Data on fluid inclusions from the main mineralizing stage ore minerals include $\mathrm{H}_{2} \mathrm{O}-\mathrm{NaCl}-\mathrm{CaCl}_{2} \pm \mathrm{MgCl} \pm \mathrm{FeCl}$ 
fluids as: (1) primary fluid inclusions with high salinities (15 to $>32 \mathrm{wt} \%$ eq. $\mathrm{NaCl}$ ), and high $\mathrm{T}_{\mathrm{h}}$ $\left(170-232{ }^{\circ} \mathrm{C}\right)$ included in sphalerite [33], and (2) moderate salinity fluids $(8-15 \mathrm{wt} \%$ eq. $\mathrm{NaCl})$ and $\mathrm{T}_{\mathrm{h}}$ ranging from 140 to $180^{\circ} \mathrm{C}$, with a few fluid inclusions of low salinities $(3-8 \mathrm{wt} \%$ eq. $\mathrm{NaCl})$ and $\mathrm{T}_{\mathrm{h}}$ between 65 and $100{ }^{\circ} \mathrm{C}$ within willemite [10]. Secondary fluid inclusions trapped in sphalerite yielded moderated salinities (10-15 wt \% eq. $\mathrm{NaCl}$ ) and $\mathrm{T}_{\mathrm{h}}$ between $100{ }^{\circ} \mathrm{C}$ to $165^{\circ} \mathrm{C}$ [34], whereas, primary fluid inclusions in late- to post-ore stage quartz have salinities ranging from 6 to $18 \mathrm{wt} \%$ eq. $\mathrm{NaCl}$ and $\mathrm{T}_{\mathrm{h}}$ between $92{ }^{\circ} \mathrm{C}$ to $196{ }^{\circ} \mathrm{C}[9,33]$. The lower homogenization temperature and lower salinity fluids in willemite were interpreted by these authors to be related to cooling and dilution of the metalliferous fluid by meteoric water during ore precipitation.

This data indicates that the mobility of the ore-related metals in the carbonate sequence of the Vazante district occurred when the mineralizing fluid exceeded $170{ }^{\circ} \mathrm{C}$, as denoted by the $\mathrm{T}_{\mathrm{h}}$ data on early sphalerite. As the hydrothermal system evolved, the hot mineralizing fluids may have progressively mixed with lower temperature and dilute fluids as indicated by the lower salinities and lower temperature fluids trapped in willemite, secondary fluid inclusions in sphalerite and late- to post-ore quartz. Episodic recharges of high temperature fluids may have occurred locally as denoted by rare high salinity and high temperature fluid inclusions in late hydrothermal phases.

Carbon $\left(\delta^{13} \mathrm{C}\right)$ and oxygen $\left(\delta^{18} \mathrm{O}\right)$ isotopic data for the least altered host dolomite is similar to the host dolomite $(1-3 \% ; 25-30 \%$, respectively $[6,9,28])$, suggesting that the fluids were buffered by the host or the fluid-rock ratio was low. Hydrothermal carbonates associated with sphalerite in the Vazante and North Extension deposits yielded the lowest $\delta^{13} \mathrm{C}$ data $(-5.9 \%$ to $+1.7 \%$ ); however, hydrothermal dolomite associated with willemite in Vazante, the North Extension and Varginha ores yielded values between $-2 \%$ to $+1.5 \%$ [ [6,9]. These data suggest a more significant input of organic carbon during sphalerite precipitation. The oxygen isotopic compositions are also distinct, in that the hydrothermal carbonates associated with sphalerite are heavier $\left(\delta^{18} \mathrm{O} 25-30 \%\right.$ ) than those associated with willemite $(15-20 \%)$. This data may suggest that fluid-rock interaction was the predominant process during sphalerite formation, whereas, fluid mixing could be involved in the willemite precipitation $[4,6,8]$. The calculated fluid composition in equilibrium with carbonates at temperatures of $150-200{ }^{\circ} \mathrm{C}$ yield a general trend towards lower $\delta^{13} \mathrm{C}\left(-7.9 \%\right.$ to $+1.7 \%$ ) and $\delta^{18} \mathrm{O}(5-15 \%)$ values during the ore stage compared to the early hydrothermal carbonates $[4,6,9]$. Calculated $\delta^{18} \mathrm{O}$ compositions of fluids in equilibrium with ore stage hematite and willemite also yielded lower $\delta^{18} \mathrm{O}$ values $(8-15 \%$ [36]). The lower oxygen isotopic values of the ore stage fluids were tentatively interpreted to be due to the input of evolved meteoric water [36,37].

Therefore, the isotopic data reported above indicates that the lower $\delta^{13} \mathrm{C}$ and $\delta^{18} \mathrm{O}$ compositions in hydrothermally altered dolomitic rocks compared to those in the unaltered dolomite, are associated with zinc mineralization.

\section{Ore System Model (Source to Trap)}

Hydrothermal ore systems require: (i) favorable sources for the ore-related metals; (ii) fluids capable of transporting these metals from the source to the site of deposition; and (iii) suitable traps to allow for ore precipitation in confined settings.

In the Serra do Poço Verde Formation carbonate sequence, during diagenesis to pre-orogenesis, the fluids were saline, at temperatures commonly below $150{ }^{\circ} \mathrm{C}$, and no significant metal mobilization was observed [9]. By contrast, in the underlying thick sequence of siliciclastic rocks (Serra do Garrote Formation), the pre-orogenic fluid flow was favorable to form anomalous concentrations of base metals in the carbonaceous units [17]. The carbonaceous siliciclastic rocks of the Serra do Garrote Formation contain high $\mathrm{Zn}$ (averaging $594 \mathrm{ppm}$ in the units with organic carbon $>1 \mathrm{wt} \%$ ), and anomalous concentrations of other ore-related elements (e.g., $\mathrm{Cu}, \mathrm{Hg}$, U and V; [17]). Petrographic observations and mineral chemistry data indicate that these metals were enriched in sulfides that formed prior to the main orogenic event, and were subsequently partially remobilized during orogenesis [17]. Accordingly, these rocks probably served as potential sources of $\mathrm{Zn}$ and otherore-related elements during the 
orogenic event that formed the dolomite-hosted zinc-rich deposits. This hypothesis is consistent with the $\delta^{13} \mathrm{C}$ signature of both sphalerite- and willemite-related fluids, which indicates interaction of the mineralizing fluids with organic carbon. Therefore, during diagenesis and prior to the orogenic event, fluid circulation in the Vazante basin was probably under thermally driven free convection or pressure-compartments regimes [38], as the timing of metal mobility and concentration in the host dolomitic units from the Serra do Poço Verde Formation and the underlying thick siliciclastic unit of the Serra do Garrote Formation are distinct (Figure 10). Other possible regional source rocks are the carbonaceous siliciclastic units of the Serra da Lapa Formation, Canastra Group and the Meso- to Paleproterozoic-basement rocks. Further research is required to address these hypotheses.
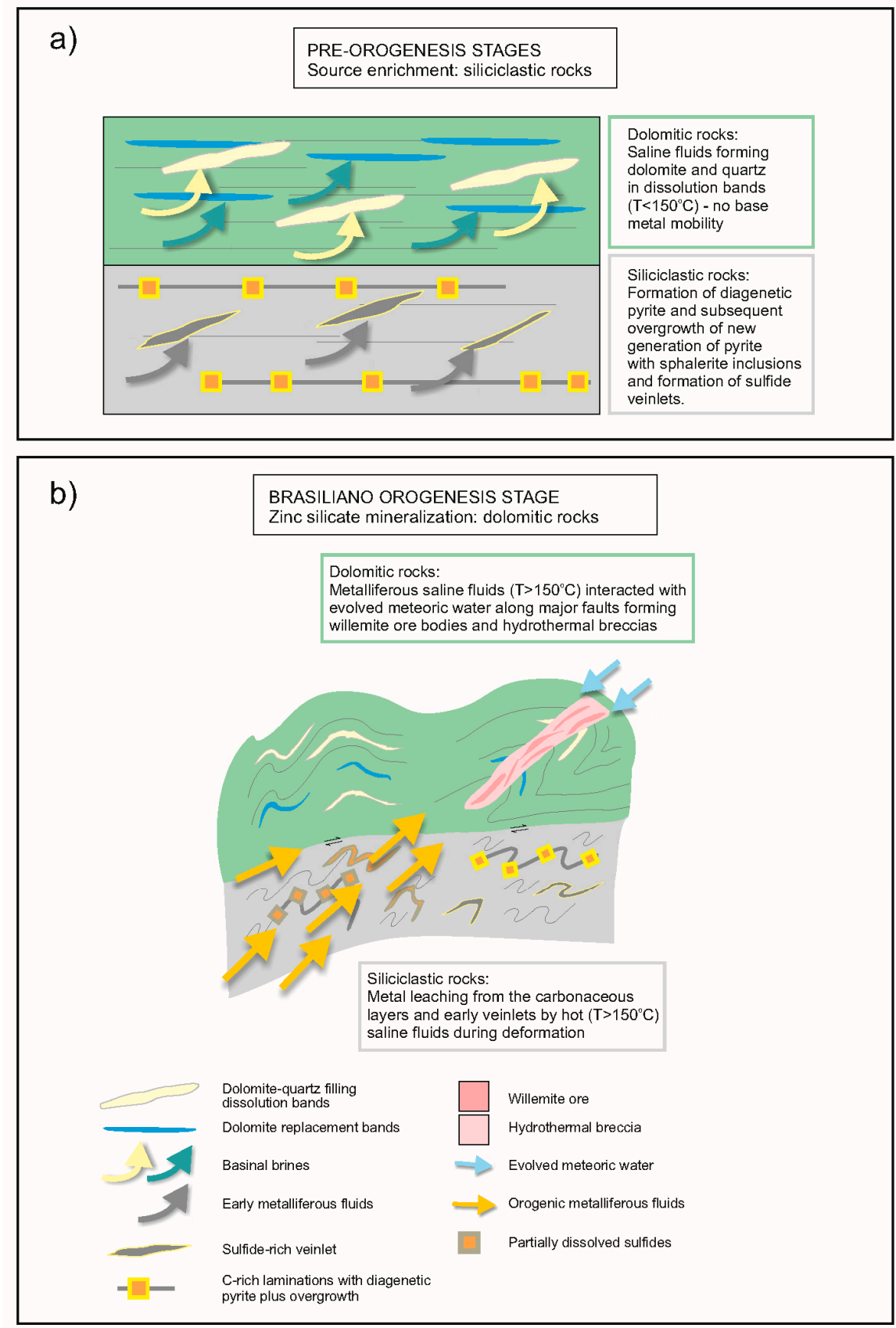

Figure 10. The Vazante Zinc Silicate Ore System: (a) from the pre-orogenesis event involving source enrichment in the siliciclastic rocks; to (b) the orogenic event involving leaching from the source rocks and formation of the zinc silicate mineralization in the dolomitic rocks. 
The willemite ore formed in zones along major faults in the dolomite unit interbedded with siliciclastic rocks of the Serra do Poço Verde Formation during the Brasiliano orogenic event $[5,6,8]$. During this stage, the fluid flow may have changed to tectonic driven flow typical of a fold-and-thrust belt. The saline fluids became hot $\left(\mathrm{T}>150^{\circ} \mathrm{C}\right)$, acidic and oxidizing enough to transport zinc and the ore-related elements from the source (possibly Serra do Garrote carbonaceous phyllite) to the deposition site in the dolomitic rocks (Figure 10). Cooke et al. [39] have shown that fluids with this composition can be derived within the basin and are able to transport the ore-related metals. The hot fluids must have been acidic enough to dissolve the dolomitic host and to favor the replacement at the early ore stages by Fe-bearing carbonate and sphalerite (if reduced $\mathrm{S}$ was available; e.g., the Vazante Mine). Under these conditions, zinc was probably transported as $\mathrm{ZnCl}_{4}{ }^{2-}$ and iron as $\mathrm{FeCl}_{3}$ [40,41]. During the main ore stage, hematite and willemite were the stable phases. The changes in the compositions of the ore and alteration minerals indicate that the hydrothermal fluids evolved to more oxidizing (hematite-stable instead of Fe-carbonate), and more alkaline conditions (willemite-stable instead of sphalerite [41]) during ore precipitation. This change in the ore system has been interpreted to be related to the mixing of the hot metalliferous fluids with evolved meteoric water, which would explain the lower temperature fluid inclusions $[4,6,9]$ and lower $\delta^{18} \mathrm{O}$ values estimated for fluids associated with willemite than sphalerite [37]. Because the Fe-carbonate and sphalerite are not associated with silicates, the $\mathrm{SiO}_{2}$ in the willemite ore may have been supplied by the evolved meteoric water. The faults may have served as the conduits for the hydrothermal fluids and meteoric water to the site of deposition. However, we cannot exclude the possibility that the hot metalliferous fluids or the meteoric water may have also circulated at the district scale using the permeable zones between carbonate and siliciclastic strata generated during the orogenic event. This would explain why the willemite ore occurs in stratigraphic levels where carbonate rocks are interbedded with siliciclastic rocks.

\section{Exploration Guidelines}

The Vazante zinc silicate deposits share many similarities with other willemite deposits [2,42-46], as summarized in Table 1 of Slezak et al. [8], suggesting that these deposits were formed by similar processes. The guidelines for exploration discussed below are based mainly on the attributes of the Vazante District, because it is the focus of this review and hosts the world largest zinc silicate deposits.

Regional Scale

- $\quad$ Thrust and fold belt tectonic setting.

- Sequence of shallow marine carbonate rocks (which host the mineralization), overlying thick sequence of immature, and organic carbon-bearing siliciclastic rocks. Siliciclastic rocks from felsic volcanic source may be to be pre-enriched in metals during diagenesis and prior to the main orogenic events and are likely one of the source rocks for the metals that were later concentrated in the dolomite rocks during the orogenic mineralizing event.

- Low grade greenschist facies metamorphism (during ore formation).

- Presence of other base-metal deposits in the region.

District and Deposit Scale

- Favorable host units with dolomitized rocks interbedded with thin layers of immature siliciclastic rocks (e.g., similar to Serra do Poço Verde Formation).

- Evidence of metal enrichment in the underlying thick sequence of siliciclastic rocks (source of metals) at the district scale (as reported in Serra do Garrote Formation).

- Permeable structures (e.g., brittle fault zones and breccias associated with regional folds and faults) to allow the flow of hot, acidic and metalliferous fluids and of the oxidizing, alkaline meteoric water. These main structures can be identified using the first vertical derivative of the total magnetic intensity from the airborne geophysical survey. 
- Hydrothermal alteration: Incipient Fe-carbonate alteration in distal zones to intense Fe-carbonate alteration in the intermediate zone and hematite and willemite at the core of the mineralized system.

- Geochemical anomalies of $\mathrm{Zn}$ and ore-related elements (e.g., As, Be, Cd, Fe, Ge, Hg, In, Mo, Ni, $\mathrm{Pb}, \mathrm{S}, \mathrm{Sb}, \mathrm{U}, \mathrm{V}$, and $\mathrm{W}$ ) in Fe-carbonate altered dolomites and increasing abundance towards hematite and willemite-rich ore. These element abundances could be used to vector to the zones of high grade mineralization. Willimite ore is associated with the highest concentrations in $\mathrm{SiO}_{2}$. Silver and $\mathrm{Cu}$ are mainly associated with the late sulfide veinlets.

- Lower $\delta^{13} \mathrm{C}$ and $\delta^{18} \mathrm{O}$ values of hydrothermally altered carbonate rocks indicating mixing of metalliferous fluids that interacted with organic-rich matter and meteoric water, respectively.

- Although detection of the willemite ore body is challenging, McGladrey et al. [3] showed that the integration of magnetic and gravimetric surveys could allow for detection of the hematite-rich willemite ore bodies.

\section{Future Studies: Prospective Settings}

Some relevant aspects need to be further investigated to better understand the ore system and therefore to improve the exploration strategy for zinc silicate deposits similar to the Vazante district. These are: (1) The possibility that the basement rocks, mafic dikes and other units from the Brasília Fold Belt could have contributed as sources of the metals associated with the Vazante ore system; (2) The origin of silica that was added to the carbonate rocks to form the willemite ore; is it sourced locally from the interbedded siliciclastic rocks or is it transported from distal sources?; (3) The intriguing absence of zinc silicate mineralization in the northern sector of the Vazante Group and only minor sulfide occurrences in the southern part. Are they related to the fluids composition or to the local source of silica and sulfur?; (4) Better understanding of the basin architecture and the fluid flow during the various stages of evolution to allow for a robust modeling of the mobility of metals in the thick carbonate units and siliciclastic units; (5) Robust dating of the mafic dikes and establishing if there is any genetic link with the stages of mineralization; and (6) Many zinc silicate deposits such as the Vazante system seem to have occurred in a specific period in time (Neoproterozoic to Cambrian). Can robust ages be obtained for these ore deposits and why do they seem to be constrained to a specific time in Earth's history?

Acknowledgments: The authors acknowledge the support of the Votoratim Metais for field work (now NEXA Resources) in the Vazante District and some of the analytical costs. Most of the analytical costs and student scholarships have been covered by G. Olivo NSERC discovery grant, CNPq and CAPES grants (Olivo, Silva, Moura, Monteiro), Queen's University, Universidade de Brasília, UNICAMP, and Universidade de São Paulo graduate scholarships and grants. The late Auguste Dardenne is also acknowledged for being a mentor and great source of inspiration in the early stages of the investigation in the Vazante District. Mark Badham's graphical assistance in preparing many of the figures and revising the document is greatly appreciated.

Author Contributions: This is a review paper and all co-authors contributed to data and interpretations presented in this manuscript. Gema R. Olivo is the senior author and supervised various graduate students' projects in the Vazante District evaluating processes in the possible source rocks, during ore transportation and in the site of deposition, being involved in field work, critical evaluation of the analytical data and interpretation, and conceptualization of the ore system. Lena V.S. Monteiro, Fernando Baia, Basilio Botura Neto contributed mainly to the detailed study of the Vazante mine, Olho d'Água, Cercado and Pamplona occurrences. Paul Slezak studied in detail the North Extension deposit and Alexandra McGladrey and Adalene M. Silva contributed mainly to the geophysical exploration and the relationship of the ore with mafic dikes. Gustavo D. Oliveira provided continuous guidance during field work and assisted in constraining the stratigraphy of the Vazante Group and the major geological controls on the zinc silicate mineralization. Igor Carvalho and Marcia A. Moura provided insights on the fluid evolution in the dolomitic rocks that host the mineralization and the characterization of the Varginha occurrence. Neil A. Fernandes and Daniel Layton-Matthews contributed to the investigation of the siliciclastic rocks as possible source of ore-related elements.

Conflicts of Interest: The authors declare no conflict of interest. The review of the Vazante district ore system was completed in collaboration with NEXA Resources (former Votoratim Metais), but the design of the study was done by the co-authors as well as the collection of samples and analyses (except for the ore resource data that was provided by NEXA resources). There were no interferences from the industrial or government sponsors in the 
interpretation of data; in the writing of the manuscript, and in the decision to publish the results. The conclusions and interpretation were solely based on the scientific data.

\section{References}

1. Large, D. The geology of non-sulphide zinc deposits-An overview. Erzmetall 2001, 54, 264-274.

2. Hitzman, M.W.; Reynolds, N.A.; Sangster, D.F.; Allen, C.R.; Carman, C.E. Classification, genesis, and exploration guides for non-sulfide zinc deposits. Econ. Geol. 2003, 98, 685-714. [CrossRef]

3. McGladrey, A.; Olivo, G.; Silva, A.M.; Oliveira, G.D.; Botura Neto, B.; Perrouty, S. The Integration of Physical Rock Properties, Mineralogy and Geochemistry for the Exploration of Large Zinc Silicate Deposits: A Case Study of the Vazante Zinc Deposits, Minas Gerais, Brazil. J. Appl. Geophys. 2017, 136, 400-416. [CrossRef]

4. Monteiro, J.V.S.; Bettencourt, J.S.; Spiro, B.; Graca, R.; Oliveira, T.F. The Vazante zinc mine, Minas Gerais, Brazil: Constraints on willemitic mineralization and fluid evolution. Explor. Min. J. 1999, 8, $21-42$.

5. Monteiro, L.V.S.; Bettencourt, J.S.; Juliani, C.; Oliveira, T.F. Geology, petrography, and mineral chemistry of the Vazante non-sulfide and Ambrosia and Fagundes sulfide rich carbonate-hosted $\mathrm{Zn}-(\mathrm{Pb})$ deposits, Minas Gerais, Brazil. Ore Geol. Rev. 2006, 28, 201-234. [CrossRef]

6. Monteiro, L.V.S.; Bettencourt, J.S.; Juliani, C.; Oliveira, T.F. Non-sulfide and sulfide rich zinc mineralization in the Vazante, Ambrosia and Fagundes deposits, Minas Gerais, Brazil: Mass balance and stable isotope characteristics of the hydrothermal alterations. Gondwana Res. 2007, 11, 362-381. [CrossRef]

7. Baia, F.H. Brechas Hidrotermais da Mina do Cercado e das Ocorrências Olho D'água, Mata II e Pamplona: Implicações Metalogenéticas e Prospectivas Para Zinco na Região de Vazante, MG. MSc Thesis, Instituto de Geociências, Universidade Estadual de Campinas, Campinas, São Paulo, Brazil, 2013.

8. Slezak, P.R.; Olivo, G.R.; Oliveira, G.D.; Dardenne, M.A. Geology, mineralogy, and geochemistry of the Vazante northern extension zinc silicate deposit, Minas Gerais, Brazil. Ore Geol. Rev. 2014, 56, $234-257$. [CrossRef]

9. Carvalho, I.A.K.; Olivo, G.R.; Moura, M.A.; Oliveira, G.D. Fluid Evolution in the Southern Part of the Vazante Group: Implications for Exploration of Base Metal Deposits. Ore Geol. Rev. 2017, 91, 588-611. [CrossRef]

10. Dardenne, M.A.; Freitas-Silva, F.H. Pb-Zn ore deposits of Bambuí and Vazante groups, in the São Francisco Craton and Brasília Fold Belt, Brazil. In Base Metal Deposits of Brazil; Gloria da Silva, M., Misi, A., Eds.; Ernesto von Sperling: Salvador, Bahia, Brazil, 1999; pp. 75-83.

11. Pimentel, M.M.; Dardenne, M.A.; Fuck, R.A.; Viana, M.G.; Junges, S.L.; Fischel, D.P.; Seer, H.J.; Dantas, E.L. $\mathrm{Nd}$ isotopes of the provenance of detrital sediments of the Neoproterozoic Brasília Belt, central Brazil. J. S. Am. Earth Sci. 2001, 14, 571-585. [CrossRef]

12. Reis, H.L.S.; Alkmim, F.F.; Fonseca, R.C.S.; Nascimento, T.C.; Suss, J.F.; Prevatti, L.D. The São Francisco Basin. In São Francisco Craton, Eastern Brazil: Tectonic Genealogy of a Miniature Continent; Heilbron, M., Cordani, U.G., Alkmim, F.F., Eds.; Springer: Cham, Switzerland, 2017; pp. 117-143.

13. Dardenne, M.A. The Brasília fold belt. In The Tectonic Evolution of South America, Proceedings of the 31st International Geological Congress, Rio de Janeiro, Brazil, 6-17 August 2000; Cordan, U.G., Milani, E.J., Thomaz Filho, A., Campos, D.A., Eds.; Secretariat Bureau: Rio de Janeiro, Brazil, 2000; pp. 231-263.

14. Misi, A.; Azmy, K.; Kaufman, A.J.; Oliveira, T.F.; Sanches, A.L.; Oliveira, G.D. Review of the geological and geochronological framework of the Vazante sequence, Minas Gerais, Brazil: Implication to metallogenic and phosphogenic models. Ore Geol. Rev. 2014, 63, 76-90. [CrossRef]

15. Dardenne, M.A.; Freitas-Silva, F.H.; Souza, J.C.F.; de Campos, J.E.G. Evolução tectono-sedimentar do Grupo Vazante no contexto da Faixa de Dobramentos Brasília. In Proceedings of the Congresso Brasileiro de Geologia, Belo Horizonte, Brazil, October 1998; Volume 40.

16. Santana, A.V.A.d. Estratigrafia, Sedimentologia e Proveniência das Unidades Superiores do Grupo Vazante na Região da Fazenda Fagundes, Paracatu, MG. Master's Thesis, Universidade de Brasília, Brasília, Brazil, 2011.

17. Fernandes, N.; Olivo, G.R.; Layton-Matthews, D.; Oliveira, G.D. Metal-enriched pelitic units in the Proterozoic sediment-hosted Vazante Zn district, Minas Gerais, Brazil: Sources of base-metals for the carbonate-hosted deposits? In Proceedings of the 14th Biennial SGA Meeting of the Society for Geology Applied to Mineral Deposits, Quebec, QC, Canada, 20-23 August 2017; p. 3. 
18. Azmy, K.; Kendall, B.; Creaser, R.A.; Heaman, L.; de Oliveira, T.F. Global correlation of the Vazante Group, Sao Francisco Basin, Brazil: Re-Os and U-Pb radiometric age constraints. Precambr. Res. 2008, 164, 160-172. [CrossRef]

19. Geboy, N.J.; Kaufman, A.J.; Walker, R.J.; Misi, A.; Oliveira, T.F.; Miller, K.E.; Azmy, K.; Kendall, B.; Pouton, S.W. Re-Os age constraints and new observations of glacial deposits in the Mesoproterozoic Vazante Group Brazil. Precambr. Res. 2013, 238, 199-213. [CrossRef]

20. Rodrigues, J.B.; Pimentel, M.M.; Buhn, B.; Matteini, M.; Dardenne, M.A.; Alvarenga, C.J.S.; Armstrong, R.A. Provenance of the Vazante Group: New U-Pb, Sm-Nd. Lu-Hf isotopic data and implications for the tectonic evolution of the Neoproterozoic Brasilia Belt. Gondwana Res. 2012, 21, 439-450. [CrossRef]

21. Fuck, R.A.; Pimentel, M.M.; Alvarenga, C.J.; Dantas, E.L. The Northern Brasília Belt. In São Francisco Craton, Eastern Brazil: Tectonic Genealogy of a Miniature Continent; Heilbron, M., Cordani, U.G., Alkmim, F.F., Eds.; Springer: Cham, Switzerland, 2017; pp. 205-220.

22. Campos Neto, M.C. Geometria e fases de dobramentos brasilianos superpostos no oeste de Minas Gerais. Revista Brasileira de Geociências 1984, 14, 60-68.

23. Freitas-Silva, F.H.; Dardenne, M.A. Evolução estrutural das formações Paracatu e Vazante na região de Paracatu-MG. REM 1992, 45, 57-59.

24. Pinho, J.M.M. Evolução Tectônica da Mineralização de Zinco de Vazante. MSc Thesis, Institute of Geosciences, Universidade de Brasília, Brasília, Federal District, Brazil, 1990.

25. Monteiro, L.V.S. Contribuição à Gênese das Mineralizações de Zinco da Mina de Vazante, MG. MSc Thesis, Instituto de Geociências, Universidade de São Paulo, São Paulo, Brazil, 1997.

26. Rostirolla, S.P.; Mancini, F.; Reis Neto, J.M.; Figueira, E.G.; Araujo, E.C. Analise estrutural da mina de Vazante e adjacências: Geometria, cinemática, e implicações para a hidrogeologia. Rev. Bras. Geosci. 2002, 32, 59-68.

27. Amaral, G.; Kawashita, K. Determinação da idade do Grupo Bambuí pelo método Rb/Sr. Congresso Brasileiro de Geologia, SBG. Anais 1967, 21, 214-217.

28. Oliveira, G.D. Reconstrução Paleoambiental e Quimioestratigráfica dos Carbonatos Hospedeiros do depósito de Zinco Silicatado de Vazante, MG. MSc Thesis, Institute de Geociências, Universidade Brasília, Brasília, Brazil, 2013.

29. Babinski, M.; Monteiro, L.V.S.; Getter, A.H.; Bettencourt, J.S.; Oliveira, T.F. Isotope geochemistry of the mafic dikes from the Vazante nonsulfide zinc deposit, Brazil. J. S. Am. Earth Sci. 2005, 18, 293-304. [CrossRef]

30. Rigobello, A.E.; Branquinho, J.A.; Silva Dantas, M.G.; Oliveira, T.F.; Neves Filho, W. Mina de zinco de Vazante, Minas Gerais. In Principais Depositos Minerais do Brasil; Schobbenhaus, C., Coelho, C.E.S., Eds.; DNPM/Companhia Vale do Rio Doce: Brasilia, Brazil, 1988; pp. 101-110.

31. Cassedane, J. Nota sobre o ambiente de sedimentação das rochas encaixando a mineralização de Vazante (MG). In Proceedings of the Anais do XXII Congresso Brasileiro de Geologia, Belo Horizonte, Brazil, September 1968; pp. 33-40.

32. Dardenne, M.A. Les Minéralisations de Plomb, Zinc, Flúor du Protérozoïque Supérieur Dans le Brésil Central. Ph.D. Thesis, University Paris VI, Paris, France, 1979; p. 251.

33. Monteiro, L.V.S. Modelamento Metalogenético dos Depósitos de Zn de Vazante, Fagundes e Ambrósia, associados ao Grupo Vazante, Minas Gerais. Ph.D. Thesis, Universidade de São Paulo, São Paulo, Brazil, 2002.

34. McGladrey, A. The Integration of Physical Rock Properties, Mineralogy, and Geochemistry for the Exploration of Large Zinc Silicate Deposits-A Case Study of the Vazante Zinc Deposits, Minas Gerais, Brazil. MSc Thesis, Queen's University, Kingston, ON, Canada, 2014.

35. Slezak, P. Geology, Mineralogy, and Geochemistry of the Vazante-Northern Extension Zinc Silicate Deposit, Minas Gerais, Brazil. MSc Thesis, Department of Geological Sciences and Geological Engineering, Queen's University, Kingston, ON, Canada, 2012.

36. Percy, E. Investigation of the Isotopic Signature of Ore of the Vazante and Northern Extension Zinc Silicate Deposits, Minas Gerais, Brazil. B.Sc. Honours Thesis, Queen's University, Kingston, ON, Canada, 2014.

37. Olivo, G.R.; Percy, E.; Kyser, K.; Oliveira, G.; McGladrey, A.; Slezak, P.; Neto, B.B. The Vazante and Northern Extension Hypogene Zinc Silicate Deposits: Evidence for Fluid Mixing During Mineralization. In Proceedings of the 21st General Meeting of the International Mineralogical Association, Johannesburg, South Africa, 1-5 September 2014. 
38. Garven, G.; Raffensperger, J.P. Hydrogeology and geochemistry of ore genesis in sedimentary basins. In Geochemistry of Hydrothermal Ore Deposits, 3rd ed.; Barnes, H.L., Ed.; John Wiley and Sons: New York, NY, USA, 1997; pp. 125-189.

39. Cooke, D.R.; Bull, S.W.; Large, R.R.; McGoldrick, J.P. The Importance of Oxidized Brines for the Formation of Australian Proterozoic Stratiform Sediment-Hosted Pb-Zn (Sedex) Deposits. Econ Geol. 2000, 95, 1-18. [CrossRef]

40. Riveros, P.A.; Dutrizac, J.E. The precipitation of hematite from ferric chloride media. Hydrometallurgy 1997, 46, 85-104. [CrossRef]

41. Brugger, J.; McPhail, D.C.; Wallace, M.; Waters, J. Formation of willemite in hydrothermal environments. Econ. Geol. 2003, 98, 819-835. [CrossRef]

42. Pirajno, F.; Joubert, B.D. An overview of carbonate-hosted mineral deposits in the Otavi Mountain Land, Namibia: Implications for ore genesis. J. Afr. Earth Sci. 1993, 16, 265-272. [CrossRef]

43. Groves, I.M.; Carman, C.E.; Dunlap, W.J. Geology of the Beltana Willemite Deposit, Flinders Range. South Australia. Econ. Geol. 2003, 98, 797-818. [CrossRef]

44. Kamona, A.F.; Friedrich, G.H. Geology, mineralogy, and stable isotopes of the Kabwe carbonate-hosted $\mathrm{Pb}-\mathrm{Zn}$ deposit, Central Zambia. Ore Geol. Rev. 2007, 30, 217-243. [CrossRef]

45. Scheider, J.; Boni, M.; Laukamp, C.; Bechstädt, T.; Petzel, V. Willemite $\left(\mathrm{Zn}_{2} \mathrm{SiO}_{4}\right)$ as a possible $\mathrm{Rb}-\mathrm{Sr}$ geochronometer for dating nonsulfide $\mathrm{Zn}-\mathrm{Pb}$ mineralization: Examples from the Otavi Mountainland (Namibia). Ore Geol. Rev. 2008, 33, 152-167. [CrossRef]

46. Boni, M.; Terracciano, R.; Balassone, G.; Gleeson, S.A.; Matthews, A. The carbonate hosted willemite prospects of the Zambezi Metamorphic Belt, Zambia. Miner. Depos. 2011, 46, 707-729. [CrossRef]

(C) 2018 by the authors. Licensee MDPI, Basel, Switzerland. This article is an open access article distributed under the terms and conditions of the Creative Commons Attribution (CC BY) license (http:/ / creativecommons.org/licenses/by/4.0/). 